\title{
A Simple Technique for Direct Immobilization of Target Enzymes from Cell Lysates Based on the SpyTag/SpyCatcher Spontaneous Reaction \\ Li-xi Cai ${ }^{1,2}$, Yuan-qing Lin², Yun-meng Chu², Xiao-pin Chen ${ }^{1}$, Li-xing Liu ${ }^{1}$, Ming Zhang ${ }^{1}$ and Guang-ya Zhang ${ }^{2, *}$
}

${ }^{1}$ College of Basic Medicine, Putian University, Putian, PR China

${ }^{2}$ Department of Bioengineering and Biotechnology, Huaqiao University, Xiamen, PR China

*For correspondence: zhgyghh@hqu.edu.cn

\begin{abstract}
[Abstract] Many of the current methods for enzyme purification and immobilization suffer from several drawbacks, such as requiring tedious multistep procedures or long preparation, and being environmentally unfriendly, due to the chemicals and conditions involved. Thus, a simple technique for direct purification and immobilization of target enzymes from cell lysates was proposed. The elastin-like polypeptides (ELPs)-SpyCatcher chimera could mediate the formation of silica carriers within seconds and the target enzymes were then covalently immobilized on silica carriers via SpyCatcher/SpyTag spontaneous reaction. These tailor-made carriers were easily prepared, with precisely controlled morphology and size, as well as none-consuming surface modification needed, which could specifically immobilize the SpyTag-fused target enzymes from the cell lysate without pre-purification.
\end{abstract}

Keywords: Silica nanoparticles, SpyCatcher, SpyTag, $\beta-1,3-x y l a n a s e, ~ E l a s t i n-l i k e ~ p o l y p e p t i d e s$, Enzyme immobilization

[Background] Enzymes are green biocatalysts with high activity in industrial manufacture. However, enzymes suffer from some problems which may hinder their industrial applications. Firstly, the process of enzyme purification is long and tedious, while in other cases it just includes one chromatographic step (Lin et al., 2020). Meanwhile, enzymes are soluble and thus need to be immobilized, for further reutilization. Hence, we propose a novel and simple technique that could directly purify and immobilize target enzymes from cell lysates (Figure 1). Briefly, new ELPs [K5V4F-40] were fused to the N-terminal of SpyCatcher (K5-C), and the K5-C chimera was purified by the inverse transition cycling (ITC) method. Then, the purified K5-C was self-encapsulated to form the K5-C modified silica NPs (K5-C@SiO $)$, via ELPs-mediated biomimetic silicification. On the other hand, the target enzyme was fused to the Nterminal of SpyTag and the SpyTag-fused enzymes could be directly purified and immobilized from cell lysate via the covalent bonds between the SpyCatcher and SpyTag. To verify the feasibility of this technique, we immobilized $\beta-1,3-x y l a n a s e$ on $\mathrm{K} 5-\mathrm{C} @ \mathrm{SiO}_{2}$, with high activity recovery, good immobilization efficiency, and excellent reusability. 


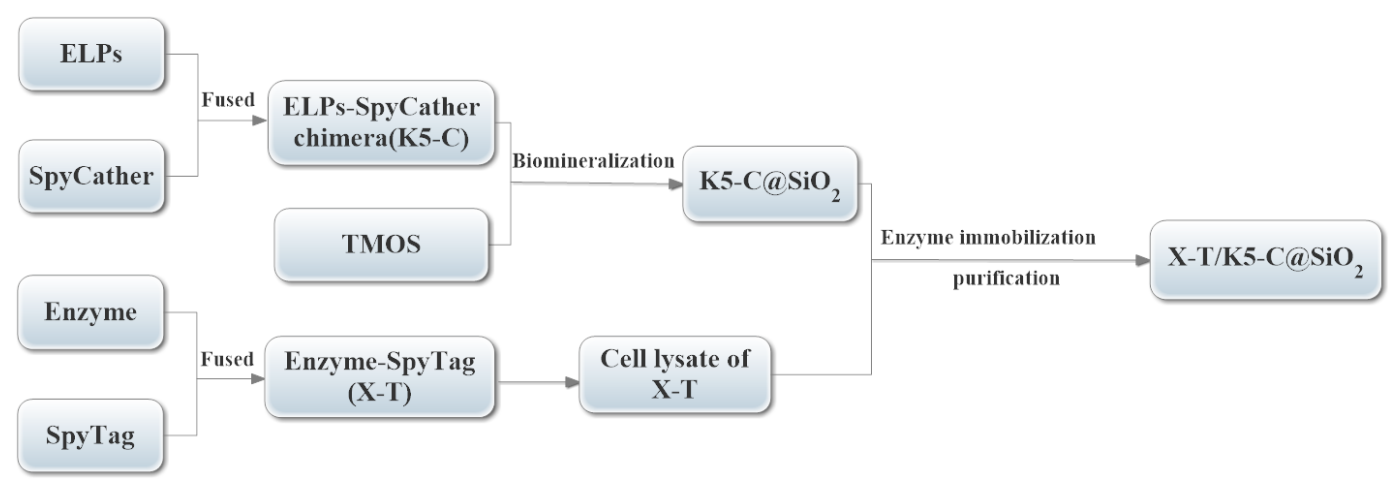

Figure 1. The flow chart of the simple technique for direct immobilization of target enzymes from cell lysates.

\section{Materials and Reagents}

1. $1.5 \mathrm{~mL}$ microtubes (Axygen, catalog number: MCT150LC)

2. $500 \mathrm{~mL}$ erlenmeyer flask (Shuniu, catalog number: GG17)

3. $0.45 \mu \mathrm{m}$ sterilized filter (Millipore, catalog number: SLHV033)

4. Dialysis bags (Solarbio, 8000-14000, catalog number: YA1072)

5. Caulerpa lentillifera (Nha trang, Vietnam,Vmax)

6. Escherichia coli BL21(DE3) cell (Klang, catalog number: KL9050510)

7. Plasmid: pET-22b(+), ambenzyl resistant, provided by Suzhou Jinweizhi Biotechnology Company, and preserved by our laboratory.

8. Yeast extract (Oxoid, catalog number: LP0021)

9. Tryptone (Oxoid, catalog number: LP0042)

10. Ampicillin (Amresco, catalog number: LP0339)

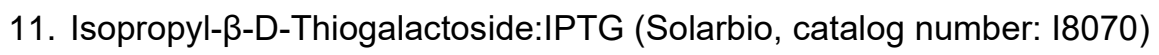

12. $\mathrm{NaCl}$ (Xilong scientific, catalog number: 7647145)

13. PageRuler prestained protein ladder (Therom, catalog number: 142546)

14. Tetramethoxysilane:TMOS (Macklin, catalog number: T819504)

15. $\mathrm{SiO}_{2}$ standard solution (Macklin, catalog number: 1821744)

16. $\mathrm{NaOH}$ (Xilong Scientific, catalog number: 100154)

17. Sulfuric acid solution (Xilong Scientific, catalog number: 7664939)

18. $\mathrm{NaClO}_{4}$ (Xilong Scientific, catalog number: 7791073)

19. Anhydrous ethanol (Xilong Scientific, catalog number: 64175)

20. Acetic acid (Xilong Scientific, catalog number: 64197)

21. Dichloroethanol (Merck, catalog number: 107073)

22. BCA protein assay kit (Yanxi, catalog number: PDBCA500)

23. SDS-PAGE gel preparation kit (Beyotime,catalog number: P0012A)

24. Nickel affinity column (Smart-Lifesciences, catalog number: SA003025)

25. Elastin-like polypeptides (ELPs, K5V4F means the ratio of $\mathrm{K}: \mathrm{V}: \mathrm{F}=5: 4: 1$ ) 
26. Phosphate buffer solution (PBS, $100 \mathrm{mmol} / \mathrm{L}, \mathrm{pH} 7.0$ ) (see Recipes)

27. Citrate phosphate buffer (CPB, 20 mmol/L, pH 6.6) (see Recipes)

28. TB medium (see Recipes)

\section{Equipment}

1. Eppendorf mixer (Eppendorf, catalog number: 5382000074)

2. $-80^{\circ} \mathrm{C}$ freezer (Therom, catalog number: 905 )

3. Beaker (Shuniu, catalog number: 056245)

4. Gel imaging analysis system (Tanon, catalog number: GIS-2008)

5. Ultrasonic cell disruption system (Scientz, catalog number: TY92-II)

6. Temperature controlled ultraviolet spectrophotometer (Analyticjena, catalog number: SPECORD40)

7. High speed refrigerated centrifuge (Eppendorf, catalog number: $5418 \mathrm{RL}$ )

8. Constant temperature shaker (HerryTech, catalog number: GG-100C)

9. Weigh scale (Sartorius, catalog number: BSA2202S)

10. Pipette (Eppendorf Research plus)

11. Scanning electron microscopy (Hitachi, catalog number: S-4800)

12. Transmission electron microscopy (Hitachi, catalog number: H7650)

13. Grinder (Leimai, catalog number: FS-100)

14. Mesh (Shuyin, catalog number:JD-12)

15. Dryer (Jinchen, catalog number: JC-9023AE)

16. Flasks (Shuniu, catalog number: GG-17)

17. Spectrophotometer (Mapada, catalog number: GDJ355)

\section{Software}

1. NCBI (https://www.ncbi.nlm.nih.gov)

2. ImageJ (NIH; https://imagej.nih.gov/ij/download.html)

3. ProtParam (http://web.expasy.org/protparam/)

\section{Procedure}

A. Extraction of $\beta-1,3-X y l a n$ from Caulerpa lentillifera

1. Wash the fresh Caulerpa lentillifera three times, and dry the clean Caulerpa lentillifera in a dryer for $24 \mathrm{~h}$. Then, grind the Caulerpa lentillifera into a powder through a 200-mesh screen.

2. Add $20 \mathrm{~g}$ powder of Caulerpa lentillifera into $1 \mathrm{~L}$ of $\mathrm{NaOH}$ solution $(300 \mathrm{mmol} / \mathrm{L})$, heat the mixture at $100^{\circ} \mathrm{C}$ for $30 \mathrm{~min}$, then centrifuge the mixture at 5,500 $\times \mathrm{g}$ at room temperature for $20 \mathrm{~min}$. Finally, discard the supernatant and then wash the precipitate with $1 \mathrm{LddH}_{2} \mathrm{O}$ under room 
temperature twice (Iriki et al., 1960).

3. Move the precipitate to a beaker containing a sulfuric acid solution $(250 \mathrm{mmol} / \mathrm{L}, 1 \mathrm{~L})$, and repeat the previous step.

4. Resuspend the precipitate in $2 \mathrm{~L}$ of $\mathrm{NaClO}_{4}$ solution (1\%), stir the mixture at $150 \mathrm{rpm}$ at $25^{\circ} \mathrm{C}$ for $2 \mathrm{~h}$, and then wash the precipitate with $\mathrm{ddH}_{2} \mathrm{O}$ twice.

5. Prepare the precipitate in $800 \mathrm{~mL}$ of $\mathrm{NaOH}$ solution $(2.5 \mathrm{~mol} / \mathrm{L})$ with stirring at $100 \mathrm{rpm}$ in an ice bath for $2 \mathrm{~h}$, discard the precipitate, and add $3.2 \mathrm{~L}$ of anhydrous ethanol to the supernatant at $4^{\circ} \mathrm{C}$ for $12 \mathrm{~h}$.

6. Centrifuge at $13,500 \times \mathrm{g}$ for $20 \mathrm{~min}$ at $4^{\circ} \mathrm{C}$ to collect the precipitate. Wash the precipitate with $100 \mathrm{~mL}$ of anhydrous acetic acid $(5.7 \mathrm{~mol} / \mathrm{L})$ and $200 \mathrm{~mL}$ of $\mathrm{ddH}_{2} \mathrm{O}$, respectively, then freezedry the precipitate at $4^{\circ} \mathrm{C}$ for $36 \mathrm{~h}$.

B. Preparation of glycol $\beta-1,3-x y l a n$

1. Mix $\beta-1,3$ xylan $(3 \mathrm{~g}), \mathrm{NaOH}$ solution $(14 \%, 150 \mathrm{~mL})$, and $18 \mathrm{~mL}$ of dichloroethanol, stirring the mixture in an ice bath at $100 \mathrm{rpm}$ for $1 \mathrm{~h}$. Then, keep the mixture at room temperature for $24 \mathrm{~h}$.

2. After $24 \mathrm{~h}$, use acetic acid to neutralize the mixture to $\mathrm{pH} 7$ with $\mathrm{pH}$ test strips, and then put it into a dialysis bag to remove impurities by $\mathrm{ddH}_{2} \mathrm{O}$ dialysis.

3. After dialysis, heat the sugar solution at $80^{\circ} \mathrm{C}$ to concentrate to $10 \mathrm{~mL}$, and then freeze-dry the sugar solution at $4^{\circ} \mathrm{C}$ for $72 \mathrm{~h}$ (Cai et al., 2020).

C. Protein expression and purification

1. Express Xyl3088 (GenBank accession No. MK253053), K5-C (No. MN136291), and Xyl3088Tag (X-T, No. MN136290) in Escherichia coli BL21(DE3) cells, respectively.

2. Inoculate $2 \mathrm{~mL}$ of $\mathrm{Xyl} 3088$ (or $\mathrm{K} 5-\mathrm{C}$ or $\mathrm{X}-\mathrm{T}$ ) and $0.2 \mathrm{~mL}$ of ampicillin $(100 \mathrm{mg} / \mathrm{mL}$ ) into $200 \mathrm{~mL}$ of TB medium in a $500 \mathrm{~mL}$ Erlenmeyer flask, and incubate at $37^{\circ} \mathrm{C}$ for $4 \mathrm{~h}$ with agitation at $200 \mathrm{rpm}$.

3. Add $1 \mathrm{~mL}$ of isopropyl- $\beta$-thiogalactopyranoside (IPTG, $0.5 \mathrm{mmol} / \mathrm{L}$ ) in TB medium, and incubate at $25^{\circ} \mathrm{C}$ for $16 \mathrm{~h}$ at $180 \mathrm{rpm}$.

4. Harvest the cells at $5,500 \times g$ for $20 \mathrm{~min}$ at $4^{\circ} \mathrm{C}$, and disrupt cells by sonication (Power: $300 \mathrm{~W}$; ultrasonic cycle: 150 runs; pulse: $4 \mathrm{~s}$; stop: $2 \mathrm{~s}$ ) on ice.

5. Centrifuge at $13,500 \times g$ for $20 \mathrm{~min}$ at $4^{\circ} \mathrm{C}$, to remove the insoluble cell debris; the supernatant (cytoplasmic fraction) is the crude enzyme extract.

6. Protein purification

a. Purify the recombinant proteins of Xyl3088 and X-T by a nickel affinity column.

i. Filter the cell lysate of Xyl3088 and X-T through a $0.45 \mu \mathrm{m}$ sterilized filter.

ii. Equilibrate the nickel affinity column with $15 \mathrm{~mL}$ of equilibrium solution $(50 \mathrm{mmol} / \mathrm{L}$ Tris$\mathrm{Cl}, 500 \mathrm{mmol} / \mathrm{L} \mathrm{NaCl}, \mathrm{pH} 7.4)$.

iii. Add the washing buffer (50 mmol/L Tris-Cl, $40 \mathrm{mmol} / \mathrm{L}$ imidazole, $500 \mathrm{mmol} / \mathrm{L} \mathrm{NaCl}, \mathrm{pH}$ $7.4)$ to the column to wash the crude protein. 
iv. Elute the Xyl3088 and X-T proteins adsorbing on the column by the elution buffer (50 $\mathrm{mmol} / \mathrm{L}$ Tris-Cl buffer, $250 \mathrm{mmol} / \mathrm{L}$ imidazole, $500 \mathrm{mmol} / \mathrm{L} \mathrm{NaCl}, \mathrm{pH}$ 7.0).

v. Dialyze the purified $\mathrm{Xyl} 3088$ and $\mathrm{X}-\mathrm{T}$ proteins extensively with $50 \mathrm{mmol} / \mathrm{L}$ Tris $-\mathrm{Cl}$ and then store at $4^{\circ} \mathrm{C}$.

b. Purify the supernatant containing soluble crude protein $(\mathrm{K} 5-\mathrm{C})$ by the method of inverse transition cycling (ITC).

i. Prepare $29.25 \mathrm{~g} \mathrm{NaCl}$ in $20 \mathrm{~mL}$ of $\mathrm{K} 5-\mathrm{C}$ solution and incubate the mixture at $37^{\circ} \mathrm{C}$ for $15 \mathrm{~min}$.

ii. Centrifuge at $13,500 \times \mathrm{g}$ for $20 \mathrm{~min}$ at $37^{\circ} \mathrm{C}$ to collect the aggregated $\mathrm{K} 5-\mathrm{C}$.

iii. Add $10 \mathrm{~mL}$ of ice-cool phosphate buffer solution (7.0) into the tube to resolubilize the aggregated $\mathrm{K} 5-\mathrm{C}$.

iv. Centrifuge at $13,500 \times g$ for $20 \mathrm{~min}$ at $4^{\circ} \mathrm{C}$ to collect the supernatant.

v. Repeat the ITC process twice, to achieve high purity of the fusion K5-C proteins (Lim et al., 2007).

c. Analyze the purity of recombinant proteins by sodium dodecyl sulfate polyacrylamide gel electrophoresis (SDS-PAGE, $12 \%$ ).

d. Calculate the purity of the Xyl3088, X-T, and K5-C by Image J.

e. For the purity of Xyl3088, SDS-PAGE yielded a clear thick band of $49 \mathrm{kDa}$ (Figure 2), it was consistent with the theoretical molecular weight values of $48853 \mathrm{Da}$ calculated by ProtParam (http://web.expasy.org/protparam/).

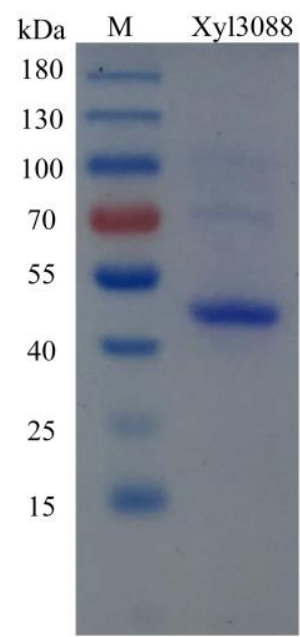

Figure 2. The SDS-PAGE of purifired recombination Xyl3088.

D. Preparation of silica nanoparticles

1. Prepare $1.522 \mathrm{~g}$ tetramethyl orthosillicate (TMOS) in $7 \mathrm{~mL}$ of $\mathrm{HCl}(1 \mathrm{mmol} / \mathrm{L})$, set the volume to $10 \mathrm{~mL}$, and keep the fresh TMOS at room temperature for $10 \mathrm{~min}$ (Cai et al., 2021).

2. Blend fresh TMOS with $\mathrm{K} 5-\mathrm{C}(300 \mu \mathrm{mol} / \mathrm{L})$ at the ratio of $1: 9(\mathrm{v}: \mathrm{V})$, and keep the reaction at $4^{\circ} \mathrm{C}$ for $10 \mathrm{~min}$. 
3. Centrifuge at $5,500 \times g$ for $3 \mathrm{~min}$ at $4^{\circ} \mathrm{C}$ to collect the silica precipitation.

4. Wash the silica precipitation three times with $1.5 \mathrm{~mL}$ of precooled PBS buffer, to collect the new formed silica nanoparticles (NPs) containing K5-C proteins (K5-C@silica).

E. K5-C leakage test

1. Resuspend the silica NPs in $3 \mathrm{~mL}$ of CPB buffer $(20 \mathrm{mmol} / \mathrm{L}, \mathrm{pH}$ 6.6). Store the suspension at $4^{\circ} \mathrm{C}$.

2. At given times, centrifuge at $13,500 \times g$ for $5 \mathrm{~min}$ at $4^{\circ} \mathrm{C}$ to collect the silica NPs and the supernatants, respectively.

3. Measure the supernatants by spectrophotometer at $280 \mathrm{~nm}$ to analyse the $\mathrm{K} 5-\mathrm{C}$ protein.

4. Add the supernatants back to tubes to resuspend K5-C@silica for further testing.

F. Characterization of K5-C@silica

Disperse the synthesized $\mathrm{K} 5-\mathrm{C} @$ silica in $1 \mathrm{~mL}$ of $\mathrm{ddH}_{2} \mathrm{O}$ and air-dry overnight. Analyze the silica morphology and size of K5-C@silica using scanning electron microscopy (SEM) and transmission electron microscopy (TEM). Calculate the elementary composition of K5-C@silica by energydispersive X-ray spectroscopy (EDS). The SEM photos of the white precipitation formed by K5-C displayed that they were spherical, rough, and their diameters ranged from 200 to $600 \mathrm{~nm}$ (Figure $3)$.

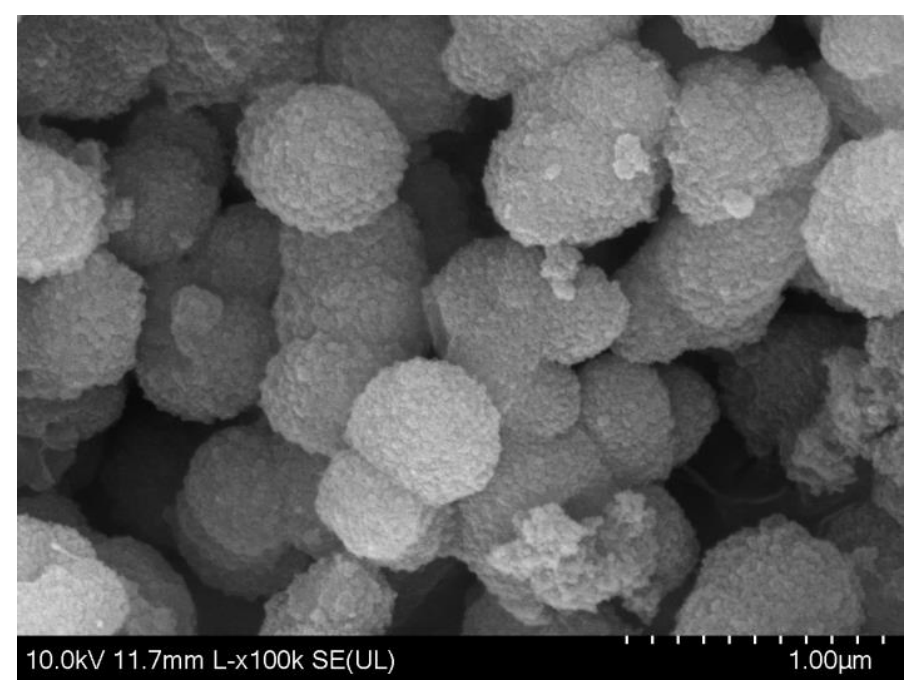

Figure 3. The SEM micrograph of K5-C@silica. Scale bar is $1 \mu \mathrm{m}$.

\section{G. Enzyme self-immobilization}

1. As SpyCatcher and SpyTag can spontaneous form the isopeptide bond in vitro, we mix the crude enzyme of X-T (300 mL) with K5-C@silica $(60 \mathrm{mg})$, and then incubate the tubes at $30^{\circ} \mathrm{C}$ for $1 \mathrm{~h}$ to formulate XTC-K5 immobilized enzymes (immobilized Xyl3088).

2. Centrifuge at $5,500 \times g$ for $3 \mathrm{~min}$ at $4^{\circ} \mathrm{C}$ to collect the immobilized $\mathrm{Xyl} 3088$. 
3. Wash the immobilized Xyl3088 with $1.5 \mathrm{~mL}$ of CPB buffer $(20 \mathrm{mmol} / \mathrm{L}, \mathrm{pH} 6.6)$ three times and keep the immobilized enzymes at $4^{\circ} \mathrm{C}$ for later use.

\section{H. Enzyme Activity Assays}

1. Assay the enzymatic activities of the free and immobilized Xyl3088, using $\beta-1,3-x y l a n$ as a substrate.

2. Estimate the enzyme activity of the free and immobilized Xyl3088, by using the modified 3,5dinitrosalicylic acid (DNS) assay.

3. Prepare $50 \mu \mathrm{L}$ of diluted enzyme and $350 \mu \mathrm{L}$ of $\beta-1,3-x y l a n(1 \%)$ together, and incubate the mixture at $45^{\circ} \mathrm{C}(\mathrm{pH} 6.6)$ for $10 \mathrm{~min}$.

4. After $10 \mathrm{~min}$, add $400 \mu \mathrm{L}$ of DNS reagent to stop the reaction, and quickly transfer the tube to a $100^{\circ} \mathrm{C}$ bath for $5 \mathrm{~min}$.

5. Define one international unit (IU) as the amount of enzyme that released $1 \mu \mathrm{mol}$ of reducing sugar per minute.

6. Assessing the optimum temperature and $\mathrm{pH}$.

a. Determine the effects of temperature on $\beta-1,3-x y l a n$ hydrolytic activity of the free and immobilized $\mathrm{Xyl} 3088$, by assessing enzyme activity in a temperature range of $25-75^{\circ} \mathrm{C}$. Define the highest activities as $100 \%$, and calculate the others as a relative percentage.

b. Meanwhile, determine the effects of $\mathrm{pH}$ on $\beta-1,3-x y l a n$ hydrolytic activity of the free and immobilized $\mathrm{Xyl} 3088$, by assessing enzyme activity in a $\mathrm{pH}$ range of 4.0-9.0.

7. Calculate the immobilization efficiency, immobilization yield and activity recovery of the immobilized enzymes as following (Sheldon, 2014; Boudrant et al., 2019).

$$
\begin{aligned}
& \text { Immobilization yield }(\%)=\frac{\text { Immobilised activity }}{\text { Starting activity of free enzyme }} \times 100 \\
& \text { Immobilization Efficiency }(\%)=\frac{\text { Observed activity }}{\text { Immobilised activity }} \times 100 \\
& \text { Activity recovery }(\%)=\frac{\text { Observed activity }}{\text { Starting activity of free enzyme }} \times 100
\end{aligned}
$$

At last, the immobilization yield of Xyl3088 was up to $96 \%$. Immobilized Xyl3088 showed $88.6 \%$ of the activity recovery and had $85.6 \%$ of the immobilization efficiency.

I. Enzyme thermal stability and reusability

1. Enzyme reusability

a. Briefly, define the first round of specific activity of immobilized Xyl3088 as $100 \%$ (Schoene et al., 2014).

b. After each cycle, centrifuge at $13,500 \times g$ for $1 \mathrm{~min}$ at $4^{\circ} \mathrm{C}$, to collect the silica NPs and the supernatant. 
c. Measure the activity of the supernatant on glycol $\beta-1,3-x y l a n$ hydrolytic ability, and caculate the reusability activity of immobilized Xyl3088 in this cycle.

d. Wash the silica NPs with CPB buffer $(20 \mathrm{mmol} / \mathrm{L}, \mathrm{pH} 6.6)$, to remove the reducing sugar.

e. Add the new substrate solution into reaction system containing immobilized $X y \mid 3088$, to start a new enzymatic reaction cycle.

2. Thermal stability

a. Incubate the free and immobilized Xyl3088 in Tris-Cl buffer $(50 \mathrm{mmol} / \mathrm{L}, \mathrm{pH} 7.0)$ without substrate at the given temperature $\left(40^{\circ} \mathrm{C}, 45^{\circ} \mathrm{C}, 50^{\circ} \mathrm{C}\right)$.

b. Calculate the residual activities at each temperature by taking the activity at $45^{\circ} \mathrm{C}$ as $100 \%$.

J. Kinetic Studies

1. Estimate the kinetic parameters of the free or immobilized Xyl3088, with increasing $\beta-1,3-x y l a n$ concentrations ranging from 1 to $10 \mathrm{mg} / \mathrm{mL}$.

2. Monitor the concentration of reducing sugar at $540 \mathrm{~nm}$ by spectrophotometer.

3. Calculate the maximum rate $(V \max )$ and Michaelis constant $(\mathrm{Km})$ of the free or immobilized Xyl3088 by using the Michaelis-Menten model.

\section{Recipes}

1. Phosphate buffer solution (PBS, $100 \mathrm{mmol} / \mathrm{L}, \mathrm{pH} 7.0$ )

A solution: $200 \mathrm{mmol} / \mathrm{L} \mathrm{Na}_{2} \mathrm{HPO}_{4}$

B solution: $200 \mathrm{mmol} / \mathrm{L} \mathrm{NaH} \mathrm{PO}_{4}$

Adjust $\mathrm{pH}$ to 7.0 with $\mathrm{A}$ solution and $\mathrm{B}$ solution.

2. Citrate phosphate buffer (CPB, $20 \mathrm{mmol} / \mathrm{L}, \mathrm{pH} 6.6$ )

A solution: $20 \mathrm{mmol} / \mathrm{L} \mathrm{Na}_{2} \mathrm{HPO}_{4}$

B solution: $10 \mathrm{mmol} / \mathrm{L}$ Citric acid

Adjust $\mathrm{pH}$ to 6.6 with $\mathrm{A}$ solution and $\mathrm{B}$ solution.

3. TB medium

Yeast extract $4.8 \mathrm{~g}$

Tryptone $2.4 \mathrm{~g}$

Glycerol $0.9 \mathrm{~mL}$

$\mathrm{ddH}_{2} \mathrm{O} 180 \mathrm{~mL}$

\section{Acknowledgments}

We thank Dr. Li Xialan and Dr. Chen Mingxia for experimental support and helpful comments on the manuscript. This protocol was supported by Foundation of Fujian Educational Committee for Young and middle-aged Teachers (JAT200496) and Natural Science Foundation of Fujian Province of China (2021J011110). 
Please cite this article as: Cai, L. et al. (2022). A Simple Technique for Direct Immobilization of Target Enzymes from Cell Lysates Based on the SpyTag/SpyCatcher Spontaneous Reaction. Bio-protocol 12(01): e4282. DOI: 10.21769/BioProtoc.4282.

The technique for direct immobilization of target enzymes from cell lysates was as described in Cai et al. (2021). "A novel all-in-one strategy for purification and immobilization of $\beta-1,3-x y l a n a s e$ directly from cell lysate as active and recyclable nanobiocatalyst". Microb Cell Fact 20(1): 37.

\section{Competing interests}

There are no conflicts of interest or competing interests.

\section{References}

1. Boudrant, J., Woodley, J. M., Fernandez-Lafuente, R. (2019). Parameters necessary to define an immobilized enzyme preparation. Process Biochem 90: 66-80.

2. Cai, L. X., Chu, Y. M., Liu, X., Qiu, Y., Zhang, G. Y. (2021). A novel all-in-one strategy for purification and immobilization of $\beta-1,3-x y l a n a s e$ directly from cell lysate as active and recyclable nanobiocatalyst. Microb Cell Fact 20(1): 37.

3. Cai, L. X., Liu, X., Qiu, Y., Liu, M. Q., Zhang, G. Y. (2020). Enzymatic degradation of algal 1,3xylan: from synergism of lytic polysaccharide monooxygenases with $\beta-1,3$-xylanases to their intelligent immobilization on biomimetic silica nanoparticles. App/ Microbiol Biot 104(12): 53475360 .

4. Iriki, Y., Suzuki, T., Nisizawa, K., Miwa, T. (1960). Xylan of siphonaceous green algae. Nature 187: 82-83.

5. Lim, D. W., Trabbic-Carlson, K., MacKay, J. A., Chilkoti, A. (2007). Improved nonchromatographic purification of a recombinant protein by cationic elastin-like polypeptides. Biomacromolecules 8: 1417-1424.

6. Lin, Y. Q., Qiu, Y., Cai, L. X., Zhang, and G. Y. (2020). Investigation of the ELP-mediated silicification-based protein self-Immobilization using an acidic target enzyme. Ind Eng Chem Res 59(44): 19829-19837.

7. Schoene, C., Fierer, J., Bennett, DSP., Howarth, P. M. (2014). SpyTag/SpyCatcher cyclization confers resilience to boiling on a mesophilic enzyme. Protein Eng 53: 6215-6218.

8. Sheldon, R. A. (2014). Green and sustainable manufacture of chemicals from biomass: state of the art. ChemInform 2014, 45(19):950-963. 